\title{
MUNICIPAL CORPORATION HELD TO BE A "PERSON" WITHIN FOURTEENTH AMENDMENT'S DUE PROCESS CLAUSE WHEN ACTION IS BROUGHT AGAINST A MUNICIPAL CORPORATION IN A FOREIGN STATE
}

In River Vale $v$. Orangetown ${ }^{1}$ the Court of Appeals for the Second Circuit held that a municipal corporation is a "person" under the due process clause of the fourteenth amendment for purposes of attacking a zoning ordinance of a contiguous municipal cosporation in another state. In order to allow construction of a large office-research complex, Orangetown, New York rezoned a residential section on the New Jersey border. River Vale, the adjoining New Jersey municipality, brought suit for damages and declaratory relief, claiming that the ordinance was "arbitrary and capricious" and that the rezoning so depreciated the value of its property as to be a deprivation of due process of law. The damage allegedly arose not only from the anticipated property devaluation and consequent decline in tax revenues but also the increased expenditures which would be necessary to handle the resulting traffic and other consequential expenses. Finding that River Vale's claimed injuries were "sufficiently direct" to confer standing, the court of appeals reversed the district court's dismissal for lack of jurisdiction.2

The common law power of municipal corporations to sue 3 includes suits against other political subdivisions." They have

\footnotetext{
1403 F.2d 684 (2d Cir. 1968).

= Notwithstanding the instant case, it is not entirely clear that a mere decrease in the tax base is a sufficient injury to allow recovery. "If, as alleged, the supposed withdrawal of property will diminish the revenues of the state, non constat that the deficiency cannot readily be made up by an increase in taxation." Florida v. Mellon, 273 U.S. 12. 18 (1927). In Franklin Township v. Tugwell, 85 F.2d 208 (D.C. Cir. 1936), the court interpreted this to mean that the remedy for a township which suffers a decreasing tax base as the only effect of defendant's action is to increase taxes. Id. at 213.

'See. e.g.. Board of Educ. v. Shelby County, 207 Tenn. 330, 339 S.W.2d 569, 584 (1960).

- Board of Educ. v. Township Council, 48 N.J. 94, 223 A.2d 481 (1966); see, e.g.. Rosebud County v. Flinn, 109 Mont. 537, 98 P.2d 330 (1940); Creskill v. Dumont, 28 N.J. Super. 26, 100 A.2d 182 (1953), aff'd, 15 N.J. 23s, 104 A.2d 441 (1954); Leonia v. Fort Lee, 56 N.J.
} 
standing to contest zoning ordinances, ${ }^{5}$ subject to the requirement that the municipality either directly own property affected by the ordinance ${ }^{5}$ or allege injury to its corporate capacity. ${ }^{7}$ However, a municipality may neither sue merely as a representative of individual citizens, ${ }^{8}$ nor contest zoning ordinances in such a representative capacity. ${ }^{9}$ There is growing recognition that zoning laws may well affect property outside an individual zone and that nearby property owners should be able to contest such laws. ${ }^{10}$ Such outside property must, however, be in close proximity to the zoned property." Moreover, zoning laws may be attacked in judicial

Super. 135, 151 A.2d 540 (1959). Moreover, there is a trend toward increased litigation between municipalities. See Evans, Overlapping. Duplication \& Conflicts Among Municipal Corporations, 7 VAND. L. Rev. 35 (1953); Kenier, The Use of the Police Povier by. Lacal Governments and Some Problems of Intergovernmental Relations, 8 J. PUB. L. 109 (1959).

s See Creskill v. Dumont, 28 N.J. Super. 26, 100 A.2d 182 (1953), aff $d, 15$ N.J. 238, 104 A.2d 441 (1954); Leonia v. Fort Lee, 56 N.J. Super. 135, 151 A.2d 540 (1959); Glen Cove v. Buxenbaum, 17 App. Div. 2d 828, 233 N.Y.S.2d 141 (1962); Bronxville.v. Francis, 206 Misc. 339, 134 N.Y.S.2d 59 (1954).

'See Somerset v. County Council, 229 Md, 42, 181 A.2d 671 (1962); cJ. Scottsdale v. Municipal Court, 90 Ariz. 393, 368 P.2d 637 (1962), noted in 5 ARIz. L. Rev. 139 (1963); 31 GeO. WASH. L. REV. 525 (1962); 16 VAND. L. ReV. 279 (1962).

${ }^{3}$ See Creskill v. Dumont, 28 N.J. Super. 26, 34, 100 A.2d 182, 192 (1953), aff $d .15$ N.J. 238, 104 A.2d 441 (1954).

8 Wheaton v. Chicago, A. \& E. Ry., 3 Ill. App. 2d 29, 120 N.E.2d 370 (1954).

${ }^{9}$ Greenbelt v. Jaeger, 237 Md. 456, 206 A.2d 694 (1965).

${ }^{10}$ Hamelin v. Zoning Bd., 19 Conn. Supp. 445,117 A.2d 86 (1955); Koppel v. Fairways, 189 Kan. 710, 371 P.2d 113 (1962); Jahnigen v. Staley, 245 Md. 130, 225 A.2d 277 (Ct. App. 1967); Baltimore v. N.A.A.C.P., 221 Md. 329, 157 A.2d 433 (1960); Santmyers v. Oyster Bay, 10 Misc. 2d 614, 169 N.Y.S.2d 959 (1957); Freeman v. Yonkers, 205 Misc. 947, 129 N.Y.S.2d 703 (1954); National Land \& Inv. Co. v. Kohn, 419 Pa. 504, 215 A.2d 597 (1965); Madden v. Zoning Bd., 48 R.1. 175, 136 A. 493 (1927); Note, Vouresldellts Permitted 10 Protest Proposed Zoning Change, 38 N.Y.U.L. Rev. 161 (1963); Note, Snob Zoning-A Look at the Econonic and Social Impact of Lolv Density. Zoning. 15 SYR. L. Rev. 507 (1964); Note, Regional Impact of Zoning: A Suggested Approach, 114 U. PA. L. Rev. 1251 (1966); Note, Zoning: Looking Beyond Municipal Borders, 1965 WASH. U.L.Q. 107; Note, Zoning Against the Public Welfare: Judicial Limitations on Municlpal Parochialism, 71 YaLe L.J. 720 (1962); Harr, Zoning for Minimum Standards: The Waine Township Case, 66 HARv. L. REv. 1051 (1953). It should be noted that there is a trend toward more rezoning of land near municipal borders. See Cutler, Legal and Illegal Methods for Controlling Community Growth on the Urban Fringe, 1961 WIS. L. Rev. 370. Coutra, Wood v. Freeman, 43 Misc. 2d 616, 25 I N.Y.S.2d 996 (1964).

"Pattison v. Corby, 220 Md. 97, 172 A.2d 490 (1961). Compare Greenbelt v. Jaeger, 237 Md. 456, 206 A.2d 694 (1965) (7 1/2 miles away); Marcus v. Montgomery County Couneil, 235 Md. 535. 201 A.2d 777 (1964) (l/4 to 3/4 mile away), where standing was denied, with Smith v. Board of Appeals, 340 Mass. 230, 163 N.E.2d 654 (1960) (both properties abutted the same pond); Mocco v. Job, 56 N.J. Super. 468, 153 A.2d 723 (1959) (more than 200 ft. away), where standing was granted. See also Leonia v. Fort Lee, 56 N.J. Super, 135, 151 
proceedings on constitutional grounds as well as through the usual administrative procedures. ${ }^{12}$ Such actions may raise questions concerning the municipality's immunity to suit. The political subdivisions of a state usually do not acquire immunity from federal jurisdiction under the eleventh amendment, ${ }^{13}$ even though the state itself would be immune. ${ }^{\text {s }}$ While a municipality is not a sovereign, it is usually immune from suit when it acts as the mere agent of the state. ${ }^{15}$ However, it would appear that where a constitutional right is infringed, application of the Ex Parte Young ${ }^{16}$ rationale would strip the subdivision of its immunity.$^{17}$

The question remains, however, whether a municipal corporation is entitled to the protection of the due process clause of the fourteenth amendment. Although private corporations are protected ${ }^{18}$ the clause has been held not to protect the United States $^{19}$ or the several states, ${ }^{20}$ on the theory that the rights

A.2d 540 (1959), where defendant's construction of a 10-foot "buffer zone" was held to be an adquate safeguard for nearby property owners.

IN Nectow v. Cambridge, 277 U.S. 183 (1928) (due process clause of the fourteenth amendment); Bell v. Studdard, 220 Ga. 756, 141 S.E.2d 536 (1965). Generally, where the constitutionality of the zoning ordinance is attacked, and not the applicability of the zoning ordinance to particular facts, the usual administrative procedure need not be exhausted before institution of judicial proceedings. Kahl v. Consolidated Gas, Elec. Light \& Power Co., 191 Md. 249, 60 A.2d 754 (1948); 3 K. Davis. Adinnistrative Law \$ 20.04 (1958); Crolly, Exhaustion of fdministrative Rentedies Before Attacking a Zoning Ordinance. 35 N.Y.S.B.J. 329 (1963); 22 MD. L. Rev. 252 (1962). But see 34 RockY MT. L. Rev. 276 (1962).

"Hopkins v. Clemson Agricultural College, 221 U.S. 636 (1911) (dictum); Lincoln County v. Luning. 133 U.S. 529 (1S90); Memphis v. Ingram. 195 F.2d 338 (8th Cir. 1952); N.M. Puterson \& Sons, Ltd. v. Chicago. 176 F. Supp. 323 (N.D. 111. 1959); Cooper v. Westchester County, 42 F. Supp. I (S.D.N.Y. 1941).

" Pacilic Fruit \& Produce Co. v. Oregon Liquor Control Comm'n, 41 F. Supp. 175, 180 (D. Ore. 1941).

is Stoulfer v. Morrison. 400 Pa. 497, 162 A.2d 378 (1960).

${ }^{15} 209$ U.S. 123 (1908).

I" Griflin v. County School Bd., 377 U.S. 218, 228, motion granted, 377 U.S. 950 (1964); Louisiana State Bd. of Educ. v. Baker, 339 F.2d 911 (5th Cir. 1964).

is Grosjean v. American Press Co., 297 U.S. 233 (1936); Progress Dev. Corp. v. Mitchell, 182 F. Supp. 681 (N.D. 111. 1960); Merced Dredging Co. v. Merced County, 67 F. Supp. 598 (S.D. Cal. 1946); Ex parte Rice, 259 Ala. 570, 67 So. $2 d 825$ (1953); private corporations are also protected by the equal protection clause. Santa Clara County v. Southern Pac. Co., 118 U.S. 394 (1886).

12 United States v. Jackson, 318 F.2d I, rehearing denied, 320 F.2d 870 (5th Cir. 1963); United States v. Nebo Oil Co., 90 F. Supp. 73 (W.D. La. 1950).

э Wisconsin v. Zimmerman, 205 F. Supp. 673 (W.D. Wis. 1962); Scott v. Frazier, 258 F. 669 (D.N.D. 1919), rev'd on other grounds, 253 U.S. 243 (1920); State ex rel. New Mexico State Highway Comm'n v. Taira, 78 N.M. 276, 430 P.2d 773 (1967). 
includible within its purview are individual or personal.21 Consequently, municipal corporations have, thus far, not been includible within the term "person," "22 although they have been held protected by similar language in at least two state constitutions. ${ }^{23}$ In Warren County v. Hester's where a county brought suit to recover taxes assessed by and paid to another state, claiming a violation of the fourteenth amendment, the due process clause was held to be "utterly without application to the political subdivisions of a state, which cannot be viewed as a person within the purview of the constitutional provision." 25 Many claims of municipal corporations to Constitutional protection arise in the course of litigation against their own states. It has been uniformly recognized that municipalities may not assert Constitutional guarantees against their parent states, because the states create and control their subdivisions. ${ }^{26}$ Municipal corporations may not assert rights against their states under the contract clause, ${ }^{27}$ the fourteenth amendment generally, ${ }^{28}$ the equal protection clause, ${ }^{29}$ or the due

\footnotetext{
${ }^{2 t}$ E.g., Wisconsin v. Zimmerman, 205 F. Supp. 673, 675 (W.D. Wis. 1962); Scott v. Frazier, 258 F. Supp. 669, 671 (D.N.D. 1919), rev'd on other grounds, 253 U.S. 243 (1920).

$=$ Los Angeles County v. Superior Court, 128 Cal. App. 522, 526, 18 P.2d 112, 113 (1933); Riley v. Stack, 128 Cal. App. 480, 482, 18 P.2d 110, 112 (1932); Bibb County v. rancock, 211 Ga. 429, 440-41, 86 S.E.2d 511, $519-20$ (1955); -Penny v. Bowden, 199 So. 2d 345, 351 (La. App. 1967); Warren County v. Hester, 219 La. 763, 781, 54 So. 2d 12, 18, cert. denied, 342 U.S. 877 (1951); Rosebud County v. Flinn, 109 Mont. 537, 539, 98 P.2d $330,332(1940)$.

In re Jensen, 28 Misc. 378, 59 N.Y.S. 653 (Sup. Ct. 1889); Narris v. Stearns, 17 S.D. 439, 97 N.W. 361 (1903).

"219 La. 763, 54 So. 2d 12, cert. denied, 342 U.S. 877 (1951).

2219 La. at 781,54 So. $2 d$ at 18 (emphasis added).

${ }_{35}$ E.g., Hunter v. Pittsburgh, 207 U.S. 161, $178-79$ (1907); Worcester v. Worcester Consol. St. Ry., 196 U.S. 539, 547-48 (1905); El Paso County Water Improvement Dist. No. 1 v. El Paso, 133 F. Supp. 894, 906 (W.D. Tex. 1955), reformed in part on other grounds and aff'd in part, 243 F.2d 927 (5th Cir. 1957), cert. denied, 335 U.S. 820 (1957); Coronado v. San Diego Unified Port Dist., 38 Cal. Rptr. 834, 846 (Ct. App. 1964); State ex rel. Spink v. Kemp, 365 Mo. 368, 283 S.W. 502, 518 (1955); Lisbon v. Lisbon Village Dist., 104 N.H. 255, 258, 183 A.2d 250, 253 (1962); Board of Educ. v. Allen, 27 App. Div. 2d 69, 71, 276 N.Y.S.2d 234, 237 (1966).

z E.g., Coleman v. Miller, 307 U.S. 433, 441 (1939) (dictum); Pawhuska v. Pawhuska Oil Co., 250 U.S. 394 (1919); Cranford County v. New York, 38 F.2d 52 (2d Cir.), cert. denied, 281 U.S. 760 (1930). See F. Strong, A.merican Constitutional LaW 510 (1950).

2x E.g., Risty v. Chicago, R.I. \& P. Ry., 270 U.S. 378, 390 (1962); Trenton v. New Jersey, 262 U.S. 182, 188 (1923); Shelby v. Pensacola, 112 Fla. 584, 587-88, 151 So. 53,57 (1933). Penny v. Bowden, 199 So. 2d 345, 351-52 (La. App. 1967); Bergen County Sewer Auth. v. Little Ferry, 7 N.J. Super. 213, 222-23, 72 A.2d 886, 891, appeal dismissed, 5 N.J. 548, 76 A.2d 680 (1950); Marshfield v. Cameron, 24 Wis. 56, 63, 127 N.W.2d 809, 813 (1964).

E.g., Williams v. Mayor \& City Council, 289 U.S. 36, 40 (1933); Newark v. New Jersey,
} 
process clause. ${ }^{30}$ This is true despite a general leniency where such suits against the parent relate to either the performance by the municipalities of their official duties ${ }^{31}$ or to enforcement of the subdivision's "proprietary," as opposed to "governmental," rights. ${ }^{32}$

It was noted in Franklin Township $v$. Tugwell ${ }^{33}$ that the rationale for not allowing suit would be inapplicable where the municipal corporation sought relief from a governmental entity separate and distinct from its parent state..$^{34}$ This holding is reiterated in River Vale v. Orangetown, where the Second Circuit recognized that a municipal corporation's disability in asserting fourteenth amendment rights against its parent state does not logically demand that it be disabled for all purposes. From this recognition, however, the court immediately moved to the conclusion that a "municipal corporation like any other corporation is a 'person' within the meaning of the fourteenth amendment ....335 It would appear that two different, although logically related questions, were answered by River Vale. First, the inability of a municipal corporation to complain of the taking of property without due process by its parent state is said to arise

262 U.S. 192, 196 (1923); Williams v. Eggleston, 170 U.S. 304, 309-10 (1898); State v. Pensacola. 126 So. 2d 566, 569-70 (Fla. 1961); Providence v. Moulton, 52 R.1. 236, 247, 160 A. 75,79 (1932).

2o E.g., Trenton v. New Jersey, 262 U.S. 182, 188 (1923); Brooklyn \& Richmond Ferry Co. v. United States, 167 F.2d 330, 333 (2d Cir. 1948); California Employment Stabilization Comm'n v. Payne, 31 Cal. 2d 210, 215, 187 P.2d 702, 705 (1947); Henderson v. Twin Falls County, 59 Idaho 97, 80 P.2d 801, appeal dismissed, 305 U.S. 568 (1938). But see Williams v. Eggleston, 170 U.S. 304, 310-12 (1898); E. Stason \& P. Kauper. Cases and Materlals oN THE LAW OF Municipal CoRporations 25 n.2 (3d ed. 1961).

I E.g., Coleman v. Miller, 307 U.S. 433, $441-42$ (1939); Board of Educ. of Central School Dist. No. 1 v. Allen, 51 Misc. 2d 297, 300, 273 N.Y.S.2d 239, 242-43 (Sup. Ct. 1966).

₹ E.g.. People v. Common Council, 28 Mich. 228, 15 Am. Rep. 202 (1873); Boonville v. Maltbie, 156 Misc. 6, 11, 281 N.Y.S. 787, 791 (Sup. Ct. 1935); Shirk v. Lancaster City, 313 Pa. 158, 163-64, 169 A. 557, 559-60 (1933). It was often hard to distinguish between "proprietary" and "governmental" functions, however. Compare the above cases with Reclamation Dist. v. Superior Court, I71 Cal. 672, I54 P. 845, 848 (1927). The distinction was apparently laid to rest in Trenton v. New Jersey, 262 U.S. 182, 191 (1923). Now, "[i]t seems rather unlikely that the United States Supreme Court will strike down as violative of the due process clause of the [] ourteenth [a]mendment any legislative controls of municipal corporations." I C. A.stieau. Municipal Corporation Law \$ 2.03 (1964). But see E. McQuillin, The Law of Muxicipal Corporations $\$ 4.20$ (3d ed. 1966).

₹ 85 F.2d 208 (D.C. Cir. 1936).

aId. at 213.

is 403 F.2d at 686. 
from the fact that municipalities are within the plenary control of state legislatures. ${ }^{36}$ Since municipal corporations exist at the pleasure of the state governments, they cannot object to a taking without due process by their creator; the "legislative body, conforming its action to the state constitution, may do as it will, unrestrained by any provision of the Constitution of the United States." ${ }^{3 \pi}$ Since River Vale involved a taking by a political entity which did not have plenary control over the municipal corporation, the Second Circuit could see no reason to withhold federal constitutional protection. Beyond this determination, however, there is a second question-one of basic constitutional interpretation. Is a state political subdivision a "person" within the fourteenth amendment? Several factors indicate that the affirmative answer of River Vale is inconsistent with analogous constitutional theories and the history of the fourteenth amendment. Rights under the fourteenth amendment have not been extended to the several states. ${ }^{38}$ An early rationale for this denial was that the amendment was intended to guarantee Negroes their freedom ${ }^{39}$ and that this intent does not include protection of a sovereign..$^{10}$ Furthermore, the Supreme Court has consistently treated fourteenth amendment rights as being guaranteed to "the individual." +11 These rights have also been spoken of as applicable to "human beings"'t2 or "natural persons. " 43 The language of the due process clause has been held to be clear enough on its face to exclude a sovereign from protection ${ }^{\text {th }}$ and this conclusion is reinforced by an examination of instances of usage of the term "person" elsewhere in the fourteenth amendment $t^{15}$ and the Constitution ${ }^{46}$ so that only natural persons

${ }^{35}$ See notes 26 \& 30 supra and accompanying text.

57 Hunter v. Pittsburgh, 207 U.S. 161, 179 (1907).

* See note 20 supra and accompanying text.

${ }^{20}$ See, e.g. Holden v. Hardey, 169 U.S. 366, 382 (1897); Strauder v. West Virginia, 100 U.S. 303 (1879); In re Slaughter-House Cases, 83 U.S. (16 Wall.) 36, 68-69 (1872).

${ }^{10}$ United States v. Nebo Oil Co., 90 F. Supp. 73, 96 (W.D. La. 1950).

" E.g., Shelley v. Kraemer, 334 U.S. 1, 22 (1948); Missouri ex rel. Gaines v. Canada, 305 U.S. 337, 351 (1938); McCabe v. Atchison, T. \& S.F. Ry., 235 U.S. 151, $161-62$ (1914).

32 E.g., Alexander v. Alexander, 140 F. Supp. 925,928 (W.D.S.C. 1956).

$\approx$ E.g., Hague v. CIO, 307 U.S. 496, 514 (1939); United States v. Biloxi Municipal School Dist., 219 F. Supp. 691, 693 (S.D. Miss. 1963); Mickey v. Kansas City, 43 F. Supp. 739, $741-42$ (W.D. Mo. 1942).

"Scott v. Frazier, 258 F. Supp. 669, 671 (D.N.D. 1919), rev'd on other grounds, 253 U.S. 243 (1920).

t5 E.g., "All persons born or naturalized in the United States, and subject to the jurisdiction thereof, are citizens of the United States and of the State wherein they reside." 
would seem to be included. Since, "in common usage, the term 'person' does not include the sovereign, "'47 and since an intent to protect the states would have presumably been made clear, the conclusion is seemingly reached that the several states were not intended to be protected. Arguably, there should be consistency of treatment between states and their subdivisions, and the River Vale conclusion is unwarranted. Municipal corporations, with regard to "individualness," differ only in degree from the United States and the several states. A contrary result in River Vale would, however, leave a municipality without a direct remedy where the threatened action is only vulnerable to attack on constitutional grounds. Indirect protection 'may be available in the form of a taxpayers' suit by individual citizens of the municipality. Such suits have long been recognized ${ }^{48}$ and may be brought in federal court.9 An obstacle to a class action by taxpayers in federal court, however, is that the amount in controversy cannot be met through aggregation of all the claims of the class. ${ }^{50}$

The terse River Vale decision establishes the seemingly anomolous rule that a municipality, while not a "person" under

U.S. Coxst. amend. XIV, $\$ 1$ (emphasis added). Also note $\$ 2$, apportioning Representatives according to population "counting the whole number of persons in each state..." (emphasis added).

${ }^{15}$ See United States v. Nebo Oil Co., 90 F. Supp. 73, 96 (W.D. La. 1950), citing U.S. CoNst. art. 1. \$2; art. 1. §6; art. I. § 7; art. 1. §9; art. 11, 1 ; art. 111, 3 ; art. IV, § 2; amend. IV.

"United States v. Cooper Corp., 312 U.S. 600, 604 (1941).

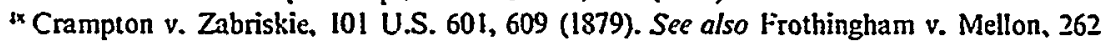
U.S. 447, 486 (1923). Such suits have been most often utilized to protect the tax fund from misuse by the municipality"s own leaders, but it has been held that there is "no distinction where . . the same injury is threatened by the action oi an outside agency. The injury to the citizen is the same, and the right to prevent the injury should be the same, whether it is threatened by the municipality or by some other governmental agency." Franklin Township v. Tugwell, 85 F.2d 208, 215-16 (D.C. Cir. 1936). See generally Note, Taxpayer's Suits: A Survey and Summar!, 69 YALE L.J. 895 (1960).

${ }^{13}$ See, e.g.. Doremus v. Board of Educ., 342 U.S. 429, 433-35 (1952); Everson v. Board of Educ., 330 U.S. I (1947).

* See. e.g.. Snyder v. Harris, 394 U.S. 332 (1969); Clark. v. Paul Gray, Inc., 306 U.S. 583 (1939); Scott v. Frazier, 253 U.S. 243 (1920); Pinel v. Pinel 240 U.S. 594 (1916): Rogers v. Hennepin County, 239 U.S. 621 (1916): Troy Bank v: G.A. Whitehead \& Co.. 222 U.S. 39 (1911); Wheless v. St. Louis, 180 U.S. 379 (1901); Fuller v. Volk, 351 F.2d 323. 327-28 (3d Cir. 1965). Contra Brown v. Trousdale, 138 U.S. 389 (1891); Note, Taxpayer's Suits: of Survey and Summar!, 69 YALE L.J. 895, 920-21 (1960).

In the instant case there were individual plaintiffs whose complaints were dismissed for failure to allege the jurisdictional amount. $403 \mathrm{F.2d}$ at 685 . 
the fourteenth amendment when it seeks relief against its parent state, becomes a "person" when its action is against an out-ofstate municipality. This is nevertheless a reasonable rule because the concepts of "person" and "non-person" are only symbols for the legal relationship between the municipal corporation and its defendant. When the defendant is not the parent state, the continued disability of the municipality would be the product of a hollow formalism. The denomination of the municipal corporation as a "person," while inconsistent with other constitutional doctrines, can also be justified by one view of the basis of the right to just compensation. American courts, in requiring just compensation for the taking of property, have failed to designate clearly the origin of that requirement. The fifth amendment prohibits the federal government from taking "private property . . . for public use, without just compensation." "This has been held to include state-owned property. ${ }^{52}$ ' In a previous clause the deprivation of "any person ['s]" property without due process is prohibited, ${ }^{53}$ but the just compensation clause itself does not contain any reference to "persons." Over two-thirds of the state constitutions ${ }^{54}$ prohibit the taking of private property without "just," "reasonable," or "due" compensation, ${ }^{55}$ but where a state has failed to protect an individual, the Supreme Court has held that the power of eminent domain is also subject to due process limitations under the fourteenth amendment. ${ }^{56}$ Thus, the fourteenth amendment's due process clause has been read as if it contained a "just compensation" provision which protects private property without requiring that a "person" be involved. Future litigation will

at U.S. CONST. amend. V.

${ }^{32}$ See St. Louis v. Western Union Tel. Co., 148 U.S. 92, 100-01 (1893); California v. United States, 395 F.2d 261, 263-64 (9th Cir. 1968).

is U.S. CoNST. amend. V.

“ H. Kaltenbach, Just Compevsation Revised $\$ 1-1-2$ (1964). Kansas courts have held that the state's eminent domain power is limited by the fifth amendment. Id. North Carolina courts hold that no constitutional limitation is needed since a property "owner's right to just compensation is an integral part of "the law of the land." De Bruhl v. State Highway :. Pub. Works Comm'n, 247 N.C. 67i, 675-77, 102 S.E.2d 229, 232-33 (1958).

ت See Bailey v. Anderson, 326 U.S. 203, 204-05 (1945).

sc Conceivably, there could be a taking with due process, which did not require just compensation. However, it has been held that "[u]nder the due process clause of the 14th Amendment ... no state can deprive an individual of his property without just compensation." De Bruhl v. State Highway \& Pub. Works Comm'n, 247 N.C. 671, 676, 102 S.E. 2d 229, 233 (1958). See Delaware, L. \& W.R.R. v. Morristown, 276 U.S. 182, 
certainly arise from the interdependent relationships of contiguous metropolitan municipalities, separated by only a state border. The River Vale decision imposes reciprocal obligations of due process on such municipal corporations.

195 (1928); Pennsylvania Coal Co. v. Mahon, 260 U.S. 393, 413-15 (1922); Hairston v. Danville \&. Wy. Ry., 208 U.S. 598, 605-07 (1908). 